\title{
Professionalism of activity: acmeological aspect
}

\author{
Irina Korshunova ${ }^{1}$, Sergey Pinaev $^{2}$, and Svetlana Tsaregorodtseva ${ }^{3,{ }^{*}}$ \\ ${ }^{1}$ Russian State University of Justice, Crimean Affiliate, Simferopol, Russian Federation \\ ${ }^{2}$ Russian and Foreign Literature, Russian University of Peoples' Friendship, Moscow \\ ${ }^{3}$ V.I. Vernadsky Crimean Federal University, Republic of Crimea, Simferopol, Prospekt Vernadskogo \\ 4, Russia
}

\begin{abstract}
Modern competition between states is entering the field of education. Education is fundamental, whose professional specialists have knowledge of its development at the domestic level and on a global scale, theory, technologies, methods of measuring the productivity of educational activities of the main participants in the educational process: leaders, pedagogues and students. The scientific and pedagogical competence of the pedagogue provides the professionalism of his activity and also includes new types of professional literacy with acmeological as a key point. To master professional pedagogical skills, it is essential to rely on the acmeological model of continuous pedagogical education. They authors give statistics of the USA educational institutions and hypothesizes that an acme-oriented teacher is a teacher with professional longevity in pedagogy.
\end{abstract}

\section{Stating the problem}

The importance of training at a high professional level cannot be overestimated. The emergence of the Bologna Process happened due to the competition in the educational field between the United States and European states. According to F. Patrick, C. Forde, A. McPhee, there is a significant number of problems in the professional activity of a pedagogue. Therefore, changes have been made to the concept of continuous professional development (CPD) for educators in the Scottish as well as English education systems. These changes were initiated by the United Kingdom governments (and more recently by the Scottish Executive) together with the General Council of Education of Scotland (GTCS) and the General Council of Education of England (GTCE). This article states that these changes did not provide a clear rationale for CPD, but instead introduced a contradiction between the concept of pedagogical education and the concept of professional training. The need for a more accurate understanding of CPD and its goals are highlighted, as well as the need to apply school approaches to lifelong professional pedagogical education. Perhaps pedagogical education should move from a technical emphasis to a model that integrates changing social processes in society, educational institutions with empowering

\footnotetext{
* Corresponding author: alatas@mail.ru
} 
teaching, ensuring a smooth transition from management to pedagogy to "new professionalism" [35].

In this regard, there is a need to develop a fundamental scientific theory based on reliable facts, laws, capable of predicting the effectiveness of professional education in the modern world. To solve this problem, a new type of a pedagogue is needed: a educatoracmeologist, a specialist in the development of a student in subject teaching, who is proficient in correctional and developing methods and methods for the development of his creative potential.

\section{Analysis of the latest achievements and publications}

According to the analysis of recent publications on this issue, modern competition between states is moving into the field of education [3]. Education is fundamental, whose professional specialists have knowledge of its development at the domestic level and on a global scale, theory, technologies, methods of measuring the productivity of educational activities of the main participants in the educational process: leaders, pedagogues and students. The scientific and pedagogical competence of the pedagogue ensures the professionalism of his activity and also includes new types of professional literacy: methodological, subject-developing, psychological, valeological, acmeological.

The problem of a person's professional growth and his success are central to acmeology, which began to form as an independent scientific discipline in the 90s. XX century

Today, the acmeological approach is considered the most innovative and promising for a modern education.

In the formation of acmeology as a science, the special contribution of the work of B.G. Ananyev, A.A. Bodalev., Derkacha A.A., Reav A.A., I. Bekh, Bondarenko O., Derkach A., Zazykin V., Kuzmina N., Maksimova V., Shvalb Yu. And others.

According to B.G. Ananyev, it is necessary to determine the influence of education on the formation of an adult and on the development of adults and children through education. B.G. Ananyev [1]. His work led to the creation of the acmeological theory of fundamental education.

According to V.P. Panasyuk, stated in the study "School and Quality: Choosing the Future" (2003), the main concept of the development of a modern general education school is the quality of education. "The quality of school education can be defined as a set of its properties, which determines its adaptability to the implementation of social goals for the formation and development of the personality in the aspects of its training, good manners, the severity of social, mental and physical traits" [9].

E.I. Belous in the work "Pedagogical conditions for the formation of professional analytical activity among undergraduates (future teachers) in a technical university" (2005) proves: psychological and pedagogical conditions of education, humanistic principles, the content of professional training, methodological support, psychological and pedagogical support of educational process, contribute to the formation of the skills of professional analytical activity of students. It also contributes to the formation of educational and professional motivation, their mastery of professional activities, development of personal and professional traits.

Kalina N.D. in the study "The system of formation of constructive-graphic skills in future specialists of architects-designers" (2005) developed a methodology for the formation of professional skills in future specialists, a program of step-by-step training of students in the "school-university" system, pointed out the pedagogical conditions for the development of creative skills of students.

To meet demands to improve the quality of education, the possibility of use of innovative approaches in professional activity, the development of creative potential, 
availability for continuous personal and professional development, it became necessary to create a concept for the modernization of education, which was developed by Petrenko A.A., 2007; Bakhtiyarova V.F., 2009; Lyz N.A., 2009; Ilyasova O.A., 2010, etc.

\section{Formulation of the goal and setting the tasks of the research}

The article hypothesizes that an acme-oriented teacher is a teacher with professional longevity in pedagogy.

N. V. Kuzmina in the work "Acmeological concept of the development of the productive competence of a specialist" (2008) indicates that maturity is a period in a person's life from an independent choice of profession and educational institution to planning the rhythm and mode of work, organizing one's time and ways to achieve the desired results. During this period, the processes of upbringing, education, training are gradually replaced by the processes of self-realization in the form of self-education, selfeducation, self-control, self-improvement, aimed at the development of creative potential [5]. According to N. V. Kuzmina, I. D. Bagaeva, G. M. Burakanova and others, professionalism of activity is the subject of acmeology. In the works of domestic researchers, much attention is paid to the concepts: "professionalism", "improving professionalism". In a short psychological dictionary edited by M.I. Dyachenko and L.A. Kandybovich professionalism is presented as a high level of readiness to fulfill the tasks of professional activity [4]. Professionalism makes it possible to achieve significant qualitative and quantitative results of labor with less expenditure of physical and mental forces based on the use of rational methods of performing work tasks. The professionalism of a specialist is manifested in the systematic improvement of qualifications, creative activity, the ability to productively meet the growing demands of social production and culture [6].

The notion "professionalism" in pedagogical activity is defined in a special study made by I.D. Bagaeva (Republic of Kazakhstan). She considers this concept as a concentrated indicator of his personality-activity essence, conditioned by the measure of realization of his civic responsibility, maturity and professional duty [2].

The author identifies three components in the structure of professionalism:

- professionalism of knowledge as the basis for the formation of professionalism in general; - professionalism of communication as a willingness and ability to use the knowledge system in practice;

- professionalism of self-improvement - dynamism, development of an integral system. $[2]$.

NV Kukharev, Head of the Department of Acmeology, State Educational Institution "Gomel Regional Institute for the Development of Education" considers professionalism as a concentrated indicator of an effective measure of activity and ways to achieve it [7].

Acmeology in pedagogy is associated with the concepts of acmeological position, acmeological model, and acmeological development of a pedagogue. Under the acmeological position of a pedagogue, we mean the comprehensive professionalism of a pedagogue as a result of self-improvement and self-development, which contributes to improving the quality of education in general, the pedagogical process and its results.

But, speaking about the student's self-improvement, one cannot but recall motivation, the only acmeological factor that directs both the teacher and the student to achieve "acme" - the top. Acmeology, as a science, is designed to help a person successfully progress towards this goal. The authors believe that the organization of teachers' work can be analyzed on the basis of some theories of motivation in order to achieve high results in mastering the subject. 
Acmeological development of a teacher is his holistic professional development as a specialist, personality and spiritually mature person, it is self-improvement, selfdevelopment both in professional and in personal and spiritual aspects, the growth of the teacher's professional self-awareness, reflection of pedagogical activity and professional behavior. It is indisputable that the acmeology of education has received a particularly wide development in the field of a person's professional activity, has revealed the ways of achieving professionalism as the top of self-realization and quality of activity.

Naturally, it is difficult to imagine that a novice teacher, who is just entering the profession, is on the path of professional development, which is impossible without trial and error, may possess a set of the above -mentioned characteristics.

To substantiate this hypothesis, we present an analysis of the problems that a young pedagogue, graduate of a pedagogical educational institution faces during the first years of work at an educational institution, related to staff turnover, insufficient psychological training and other aspects. In addition, we provide statistical data on the turnover of personnel in "elementary schools" in the United States in terms of age, and an analysis of the teacher's activities in relation to his teaching quality, teaching experience. Finally, the assumption is made that acme-oriented teachers are pedagogues who have professional longevity in pedagogy.

Research shows that among the factors associated with teaching, the pedagogue is the most important. According to the Rand Education magazine [24], while teaching, for example, reading, the teacher influences the learning process two to three times more than any other school factor. However, one of the main problems in the educational system is also revealed, which is associated with the turnover of staff among young teachers with a professional experience of no more than 5 years. In some American states, this process is compared to an epidemic. "At the national level, about $30 \%$ of new teachers leave the profession after 5 years, and the teacher turnover rate is $50 \%$ higher in schools with high poverty rates compared to better-off ones" (Ronfeldt, Lankford, Loeb, \& Wyckoff, 2011) [25]. This trend significantly lowers the level of training and the formation of professionalism in the activities of the pedagogue.

Presentation of the research material. Approximately 6,000 pedagogues retired after their first year at school in 1987-88. The number of pedagogues leaving school increased threefold over the period 2007-18. Overall, the percentage of educators who left their careers after their first year of employment increased by 34\% between 1988 and 2008 (Ingersoll et al., 2014) [21]. A significant number of factors influencing the departure of teachers from the profession have been identified, and the numbers are staggering. Consequently, the problem of turnover among young teachers is relevant. According to data compiled by the National Center for Education Statistics (Crandell \& Howell, 2009) [11], one third of pedagogues leave the profession within three years. More than $40 \%$ of pedagogues leave the profession within the first 5 years of teaching, and the percentage rises to $50 \%$ of teachers working in urban school districts (Crandell \& Howell, 2009).

Interesting data are also given by Goldring, R., Taie, S., \& Riddles, M. (2014) [19]: "among teachers of general educational schools with 1-3 years of work experience, $80 \%$ stayed in their school, 13\% went to another school, and 7\% left teaching in 2012-13". Researcher Guin (2014) surveyed 66 elementary schools in a large urban district to find out the relationship between school turnover and learning outcomes in reading and math. The study found that in schools with higher turnover rates, students score is lower across disciplines. Guin also admits that, in addition to staff turnover, other reasons for poor performance are poverty, crime, or poor school leadership. However, the variability of the teaching staff is the dominant indicator affecting student achievement. $42 \%$ of the interviewed educators report dissatisfaction with their work, their desire to get another job or improve working conditions. 
One third of the school young teachers leaves the profession within three years. More than $40 \%$ of educators leave within the first 5 years of employment (Crandell \& Howell, 2009) [15]. Despite this, a significant percentage of pedagogues, who have been engaged in their profession for a long time, was identified. The category of "longevity" includes pedagogues with 30 years of teaching experience, educators with high pedagogical skills, acme-oriented teachers. A correlation between the pedagogical experience and the time spent by the pedagogue with students at extracurricular activities was distinguished: the more time an educator spends with students outside school, the longer he stays in his profession. Crandell \& Howell (2009) [15]. Many researchers believe that the time spent by a pedagogue with students at extracurricular activities forms the teacher's "acme" and affects his professional longevity. Among other components of the professional longevity of acme-oriented teachers, as a result of a survey in 66 primary schools, nationality, living in a democratic society, and appropriate financial remuneration were noted.

Similar conclusions are supported by domestic researchers and teachers of secondary educational institutions, such as O. Anisimova, E. Belolyubskaya, R. Demyanchuk, O. Zhukov, N.S. Rossoshanskaya and others.

It is a well-known fact that involution (from Latin involutio-coagulation, the process of "reverse development") of sensory-perceptual functions does not necessarily lead to a sharp professional decline. Therefore, some age-related changes cannot lead to significant changes in the usual professional activity.

\section{Conclusions}

Teaching and learning are considered by many scientists and educators as a combination of science and art. To master professional pedagogical skills, it is necessary to rely on the acmeological model of continuous pedagogical education. It takes time to master and develop it, and this is an indisputable fact. As the above-said statistics shows, pedagogues with insufficient professional experience cannot be pedagogues-acmeologists and vice versa, acme-oriented pedagogues have professional longevity.

Undoubtedly, the regular improvement of pedagogical skills, multiplied by many years of professional experience, is one of the key factors contributing to the professional longevity of an acme-oriented teacher, which is confirmed by the thought of Philip Moeller "people who have a high educational professional level live longer, and postpone their life final."

\section{References}

1. B.G. Ananiev, Man as a subject of knowledge, 339 (Leningrad State University, 1968)

2. I.D. Bagaeva, Professionalism of pedagogical activity and the basis of its formation in the future teacher, 338 (Ust-Kamenogorsk, 2011)

3. E.P. Bocharova, Acmeological approach to education, Humanitarian research in Eastern Siberia and the Far East, 4, https://cyberleninka.ru/article/n/ akmeologicheskiy-podhod-k-obrazovaniyu (date accessed: 09/08/2020) (2008)

4. M.I. Dyachenko, L.A. Kandybovich, Brief psychological dictionary: Personality, education, self-education, profession, 399 (Minsk, Halton, 1998)

5. N.V. Kuzmina, Acmeological concept of the development of the productive competence of a specialist, 62 (St. Petersburg, Kovrov, 2008)

6. N.V. Kuzmina, The subject of acmeology, 24 (St. Petersburg, Acmeological Academy, 1995) 
7. N.V. Kukharev, On the way to professional excellence: A book for a teacher, Education, 159 (1990)

8. V.N. Maksimova, N.M. Poletaeva, Acmeology of postgraduate education of a teacher, 225 (St. Petersburg, 2004)

9. V.P. Panasyuk, School and quality: choice of the future, (St. Petersburg, KARO 2003)

10. G. Barnes, E. Crow, B. Schaefer, The cost of teacher turnover in five school districts: A pilot study (Arlington, VA, National Commission of Teaching and America's Future)

11. P. Barth, N. Dillon, J. Hull, B. Holland-Higgins, Fixing the holes in the teacher pipeline: An overview of teacher shortages (Arlington, VA, Center for Public Education, 2016)

A. Buhm, Global Student Mobility 2025: Analysis of Future Labour Market Trends and the Demand for International Higher Education, 6 (Australia, IDP, 2013)

12. Said W. Edward, Culture and imperialism, (New York, Vintage Books, 1994)

13. Center for Public Education (The). Teacher quality and student achievement: Research review. Retrieved from: http://www.centerforpubliceducation.org/MainMenu/ Staffingstudents/Teacherquality-and-studentachievement (2005).

14. R. Crandell, J. Howell, An analysis of teacher choices: Transfers, attrition, and retirement, Retrieved from www.csus.edu/indiv/h/howellPaper/teacher attrition jan2009.pdf (2009)

15. J. Creswell, Qualitative inquiry and research design: Choosing among five approaches, 3rd ed. (Thousand Oaks, CA: Sage, 2013)

A. Dyson, C. Genishi, The need for story: Cultural diversity in classroom and community, (Urbana, IL, National Council of Teachers of English, 1994)

16. J. Gelbrich, American Education. The second half of the 20 The century: Post World War II and beyond (OSU - School of Education, 1999)

17. R. Goldring, S. Taie, M. Riddles, Teacher attrition and mobility: Results from the 2012-13 teacher follow-up survey, Retrieved from http://nces.ed.gov/pubsearch (Washington, DC: U.S. Department of Education, National Center for Education Statistics, 2014)

18. D. Hasiotis, et al., The Mirage: Confronting the hard truth about our quest for teacher development, Education field struggles to attract millennials. Retrievedfrom:https://www.tasb.org/Services/HRServices/Hrexchange/2016/Septemb er-2016,-Vol-1/b (Brooklyn, NY, The New Teacher Project. HR Exchange, Septemberk, 2016)

19. R. Ingersoll, Teacher turnover and teacher shortages: An organizational analysis, American Educational Research Journal, 38 (3), 499-534, Retrieved from http://repository.upenn.edu/gse_pubs/94

20. M. Kurtz, Teacher Retention: Why Do They Stay?, 229 (ProQuest LLC, Ed.D., Edgewood College, 2015)

21. P. Moeller, https://money.usnews.com/money/blogs/the-best-life/2013/09/09/ longevity-annuitiesgrowing-in-p

22. Rand Education, Teachers matter. Understanding teachers' impact on student achievement, Retrieved from http://www.centerforpubliceducation.org/Main (2012)

23. M. Ronfeldt, H. Lankford, S. Loeb, J. Wyckoff, How teacher turnover harms student achievement (Cambridge, MA: National Bureau of Economic Research, 2011) 
24. Said Edward W., Culture and imperialism (New York: Vintage Books, 1994)

25. Cipto Wardoyo, Aulia Herdiani, Sulikah, Teacher Professionalism: Analysis of Professionalism Phases, International Education Studies, 10, 4, 90-100 (2017)

26. P. Sullivan, Searching for the Intercultural, Searching for the Culture, Wiley Online Library, https://onlinelibrary.wiley.com/doi/abs/10.1002/j.1834-4461.2005.tb02879.x (2015)

27. The Influence of a Principal's Length of Service and School Socioeconomic Classification on Teacher Retention Rates in New Jersey Middle Schools

28. Laura Hasselquist; Graves, Nicole A., CTE Teacher Retention: Lessons Learned from Mid-Career Teachers - Career and Technical Education Research, (2020)

29. Babo, Gerard; Petty, J. Douglas, Journal for Leadership and Instruction (2019)

30. Gerard; Petty, J. Douglas, The Influence of a Principal's Length of Service and School Socioeconomic Classification on Teacher Retention Rates in New Jersey Middle Schools Babo, Journal for Leadership and Instruction (2019)

31. Joachim; Goyette, Nancy; Robertson, Jean E., Happiness in the Classroom: Strategies for Teacher Retention and Development De Stercke, https:/eric.ed.gov/

32. Teacher professional development: an international review of the literature Eleonora Villegas-Reimers UNESCO: International Institute for Educational Planning https://unesdoc.unesco.org/ark:/

33. https://www.semanticscholar.org/author/ M.-Akiba/81507418F. Patrick, C. Forde, A. McPhee

34. Psychology, Journal of In-Service Education, (Published, 2003) 